\title{
JFINTERNATIONAL
}

International Journal of Filologia (IJOF)

ISSN: 2667-7318 Yıl: 4, Sayı: 5, Yayımlanma Tarihi: 30.06.2021

EKOELEŞTİREL BİR YAKLAŞIMLA
POST/ROMANTIK UNSURLARIN
ANALIZİ: SÜR PULLUĞUNU
ÖLÜLERINN KEMIKLERİ ÜZERINDE
AN ANALYSIS OF POST/ROMANTIC ELEMENTS WITH AN ECOCRITICAL APPROACH: DRIVE PLOW OVER THE BONES OF THE DEAD

Dr. Öğr. Üyesi Engin BÖLÜKMEŞE

ID Eskişehir Osmangazi Üniversitesi, Fen Edebiyat Fakültesi, Karşılaştırmalı Edebiyat Bölümü. enginb@gmail.com

\section{Beda SÖNMEZ}

ID Eskişehir Osmangazi Üniversitesi, Ssoyal Bilimler Enstitüsü, Karşılaştırmalı Edebiyat Ana Bilim Dalı bedasonmezz@gmail.com

Makale Bilgisi / Article Information

Makale Türü: Araştırma Makalesi

DOI: ijof.911376

Yükleme Tarihi: 07.04.2021

Kabul Tarihi: 17.05.2021

Yayımlanma Tarihi: 30.06 .2021

Sayı: 5

Sayfa: $14-30$
Article Information: Research Article

DOI: ijof.911376

Received Date: 07.04.2021

Accepted Date: 17.05.2021

Date Published: 30.06 .2021

Volume: 5

Page: 14-30

Yazar Engin Bölükmeşe ’nin bu makaledeki katkı oranı \%50, yazar Beda Sönmez'in katkı oranı \%50’dir.

\section{Atıf / Citation}

Bölükmeşe, E. ve Sönmez B. (2021). Ekoeleştirel Bir Yaklaşımla Post/Romantik Unsurların Analizi: Sür Pulluğunu Ölülerin Kemikleri Üzerinde. International Journal Of Filologia, 4 (5), 14-30.

Bölükmeşe, E. ve Sönmez B. (2021). An Analysis of Post/Romantic Elements with an Eco-Critical Approach: Drive Plow over the Bones of the Dead. International Journal of Filologia, 4 (5), 14-30. 


\title{
Dr. Öğr. Üyesi Engin BÖLÜKMEŞE - Doktora Ö̆̆grencisi Beda SÖNMEZ
}

\section{EKOELEŞTİREL BİR YAKLAŞIMLA POST/ROMANTİK UNSURLARIN ANALİZİ: SÜR PULLUĞUNU ÖLÜLERİN KEMIKLERİ ÜZERİNDE}

\author{
An Analysis of Post/Romantic Elements with an Eco-Critical Approach: Drive Plow \\ over the Bones of the Dead
}

\begin{abstract}
ÖZ
Bu çalışmada Polonyalı yazar Olga Tokarczuk tarafından kaleme alınan Sür Pulluğunu Ölülerin Kemikleri Üzerinde adlı eserde, ekoeleştirel bir yaklaşım ile romantik unsurların izi sürülecektir. 18. yüzyılın ilk yarısında ortaya çıkan ve tüm dünya edebiyatlarını etkisi altına alan Romantizm akımı, 21. yüzyılda okuyucuyla buluşmuş çağdaş bir edebi eser üzerinden analiz edilerek günümüz bakış açısı ve değişen dünya algısı çerçevesinde 'post romantik' bir yorumla irdelenecektir. Romantizm döneminden itibaren tabiat ve çevre, yazar ve şairler için vazgeçilmez bir unsur olagelmiştir. Doğa bilimleri ile edebiyat biliminin kesişme noktasını oluşturan ekoeleştiri, Sanayi Devrimi sonrası ortaya çıkan çevre kirliliği, doğal kaynakların azalması, bazı bitki ve hayvan türlerinin yok olması, bazılarının da tehlike altında olması gibi küresel sorunların edebiyata yansımalarını araştırır. Tabiatın, eserin öznelerinden biri olduğu Sür Pulluğunu Ölülerin Kemikleri Üzerinde roman1, modern dünyada değişen doğa algısının, sanayileşme sonrası baş gösteren tabiat tahribatının çarpıcı bir üslupla işlendiği fiktif bir eserdir. Bu anlamda esere konu edilen tahribat, modern insan-doğa çatışması, ekoeleştiri yöntemi kullanılarak incelenecektir.

Anahtar Kelimeler: Romantizm, Post/Romantizm, Ekoeleştiri, Olga Tokarczuk, Sür Pulluğunu Ölülerin Kemikleri Üzerinde.
\end{abstract}

\begin{abstract}
In this study, romantic elements will be traced with an eco-critical approach in Drive Your Plow over the Bones of the Dead, written by Polish author Olga Tokarczuk, The romanticism movement, which emerged in the first half of the 18th century and influenced all world literatures, will be analyzed through a contemporary literary work that met with the reader in the 21st century, and will be examined with a "post-romantic" interpretation within the framework of today's perspective and changing world perception. Nature and environment have been indispensable for writers and poets since the era of Romanticism. Ecocriticism, which constitutes the intersection point of natural sciences and literature, explores the reflections of global problems -such as environmental pollution, the depletion of natural resources, the extinction of some plant and animal species, and the endangerment of some- that emerged after the Industrial Revolution. The novel Drive Your Plow over the Bones of the Dead, in which nature is one of the subjects of the work, is a fictitious work which handles the changing perception of nature in the modern world and the destruction of nature that emerged after industrialization in a striking style. In this sense, the subjects of the work which are the destruction and the modern human-nature conflict will be analyzed using eco-criticism method.
\end{abstract}

Keywords:Romanticism,Post/Romanticism, Ecocriticism, Olga Tokarczuk, Drive Your Plow over the Bones of the Dead. 


\section{Giriş}

Tarihsel olarak Romantizm akımının doğuşunun izlerini sürmek ve başlangıç noktasını 18. yüzyılın ortalarına kadar götürmek mümkündür. Buna karşılık 'Romantizm akımı son buldu mu?' sorusunun yanıtı belirsizdir. Michael Löwy ve Robert Sayre'in, Isyan ve Melankoli: Moderniteye Karşı Romantizm isimli kitaplarında yazdığına göre "romantik bakış açısı, 18. yüzyılın ikinci yarısında yerleşmiş ve bir daha da yok olmamıştır" (Löwy\&Sayre, 2016: 33). Kendisinden sonra ortaya çıkan sanat ve edebiyat akımlarının gölgesinde kalan romantizm hız kesmiş olsa da tamamıyla yok olmamış, farklı şekiller alarak değişen dünya düzenine uyum sağlamıştır. Bu doğrultuda 20. yüzyılda ortaya çıkan çevre farkındalığı, otoriteye karşı örgütlü isyanların artması, bireyin değer olarak yükseliş kaydetmesi gibi bazı sosyo-kültürel hareketlerin dinamiğini oluşturan itici gücün romantizm ruhu olduğu söylenebilir (bkz. Keskin, 2017: 86).

Sanayileşme sonrası insanın tüketimi uğruna doğanın dengesini bozan, gelecekte büyük sorunlara yol açacağını hesaba katmadan yaşamsal kaynakları hızla tüketen insan merkezli yaşam biçiminin benimsenmesi çeşitli çevre sorunlarının baş göstermesine sebep olmuştur. İnsan ile doğanın bozulan ilişkisini onarmak, çevre sorunlarına dikkat çekmek ve insanın merkezde olduğu düzeni yıkmak üzere ortaya çıkan çeşitli yaklaşımlardan biri de ekoeleştiridir. Herhangi bir ülkede, toplumda ya da çevrede gelişen edebiyatın doğadan ve çevresindeki kültürel, sosyal ve siyasî hareketlerden bağımsız olarak yapılandığı düşünülemez. Bu anlamda ekolojik faaliyetlerin edebiyatta tezahürü olarak ortaya çıkan ekoeleştiri, çok genel bir ifadeyle edebiyat metni ile çevre arasında irtibat kurmaya çalışır. Ekoeleştiri ifadesi yerine "çevreci eleştiri" ifadesi de kullanır.

Küreselleşen dünyada çevresel sorunları kurmaca eserlere taşıyan sanatçılar, edebiyatın imkânları dâhilinde ekolojik problemleri tartışarak hem bireyde farkındalık ve çevresel bilinç oluşturmaya hem de yaşadıkları gezegenle uyum ve ahenk içinde yaşamaya çağrıda bulunurlar. Sür Pulluğunu Ölülerin Kemikleri Üzerinde eserinin yazarı Olga Tokarczuk, söz konusu çevre aktivisti yazarlardan biridir. 1962 yılında dünyaya gelen Polonyalı yazar Olga Tokarczuk edebiyat dünyasına ilk olarak 1989 yılında Miasta w lustrach (Aynadaki Kentler) başliklı şiir kitabı ve $\mathrm{Na}$ Przełaj adlı dergide yayımlanan kısa öyküleriyle girmiştir. Ancak 1993 yılında yayımlanarak Polonya Kitap Yayımcıları Derneğinden roman dalında en iyi çıkış yapan yazar ödülünü almasını sağlayan Podróż ludzi Księgi (Kitap İnsanlarının Yolculuğu) başlıklı yapıtı, Tokarczuk'un sanatında çıkış noktası olarak kabul edilir (bkz. Klein, 2016: 1897). Yazar, olağanüstü unsurlar ile saf gerçekliği harmanlayarak kaleme aldığ 1 eserleriyle karakteristik bir söylem oluşturmuştur. Türkçeye Koşucular olarak çevrilen kitabıyla 2018 Man Booker ödülünü ve 2019 yılında Nobel Edebiyat Ödülü'nü kazanan yazar, sınırları aşan hayal gücü ve yansıttığ1 yaşam biçimi ile birçok edebiyat eleştirmeninden övgüler almış ve uluslararası bir başarı elde etmiştir (bkz. Karnewar, 2020: 2). Yazarın Türkçeye çevrilen eserleri ise şunlardır: Aç Gözünü Artık Yaşamıyorsun (öykü), Gündüzün Evi Gecenin Evi (roman), Koşucular (roman), Sür Pulluğunu Ölülerin Kemikleri Üzerinde (roman), Kadimzamanlar ve Diğer Vakitler (roman). Tokarczuk eserlerini, romantizm dönemi yapıtlarında sıkça başvurulan bir yöntemle 
karşıtlıklar arasındaki gerilim üzerine kurar. Doğaya karşı kültür, akla karşı delilik, erkeğe karşı kadın, yuvaya karşı yabancılaşma, doğaya karşı insan gibi ikilikleri kullanarak dinamik bir anlatım yakalamıştır. Sür Pulluğunu Ölülerin Kemikleri Üzerinde eseri, modern dünya düzeninin geldiği son noktada yaşanan doğa katliamına dikkat çekmektedir. Bu doğrultuda çalışmanın inceleme yöntemi olan ekoeleştirel yaklaşıma değinmekte fayda vardır.

\section{Ekoeleştiri Nedir?}

Ekoeleştiri (ecocriticism), 1970’lerin sonunda türetilen bir terimdir. Bu terim, hayvan ve bitki yapılarının fiziksel yaşam alanlarıyla ve birbirleriyle karşıllklı ilişkilerini inceleyen çevrebilim (ekoloji) ile edebiyat eleştirisinin birleştirilmesi ile ortaya çıkmıştır. Sanayi Devrimi ile başlayan endüstrileşmenin bir sonucu olarak 20. yüzyılda hissedilmeye başlanan çevre sorunlarına karşı yöneltilmiş bir yaklaşım olan ekoeleştiri, doğa bilimleriyle edebiyat biliminin kesişme noktasını oluşturan bir yöntemdir. Teknolojik gelişmelerle birlikte hız alan ve tüketimin merkezde yer aldığı makineleşme ile ortaya çıkan çevre kirliliği, doğal kaynakların azalması, bazı bitki ve hayvan türlerinin ortadan kalkması, bazılarının da tehlike altında olması gibi küresel sorunlar çevre duyarlılığını gündeme getirmiştir. Bu doğrultuda çevre bilincinin tüm insanlığa yayılması ve doğa tahribatının önlenmesi yolunda bazı çalışmalar yapılmaya başlanmıştır.

Çevrenin bilinçsizce yok edilmesi ve ekolojik sistemin bozulmasına karşı olarak ilk kez 1972'de Bükreş’te Arne Naess tarafından “Üçüncü Dünyanın Geleceği Konferansı"nda Derin Ekoloji kavramı ortaya atılmıştır. Bu görüşe göre insan doğaya karşı bir tutum sergilemekten kaçınmalı ve onun bir parçası olduğunu kabul etmelidir. Ekoeleştirinin kavramsal çerçevesinin oluşmasına katkı sağlayan kuramcılar şöyle sıralanabilir: Aldo Leopold, John Muir, Edward Abbey, Henry David Thoreau ve Terry Tempest. Ekoeleştiri terimini ilk kullanan kişi ise William Ruckert'tır (bkz. Bayraktar, 2015: 141). Ruckert ekoeleştiri terimini ilk kez 1978 yılında yayımladığı Edebiyat ve Çevrebilim: Çevreci Eleştiri Üzerine Bir Deneme adlı makalesinde kullanmıştır.1995 yılında ilk ASLE (Association for the Study of Literature and Environment/Edebiyat ve Çevre Çalışmaları Kuruluşu) konferansıyla birlikte bu alanı tanımlayan kitap ve antolojiler yayınlanmıştır. Özellikle Lawrence Buell'in Çevresel İmgelem, Glotfelty ve Fromm'un Çevreci Eleştiri Seçkisi adlı kitapları geniş bir okur kitlesiyle buluşmuştur (bkz. Gökalp Alpaslan, 2013: 3). Ekoeleştirinin en bilinen tanımlarından biri, Cheryll Glotfelty'e aittir. Yazarın 1996 yılında yayımladığı Çevre Krizi Çağında Edebiyat Çalışmaları eserinde ekoeleştiri, "edebiyat ve fiziksel çevre arasındaki ilişkinin incelenmesi" şeklinde tanımlanmıştır (akt. Oppermann, 2012: 9). Ekoeleştiri üzerine kapsamlı çalışmaları olan Serpil Oppermann ise ekoeleştiriyi şu şekilde tarif etmiştir: "Edebiyat eleştirisi ve kuramları içinde, edebiyat ve kültür metinlerini çevreci bir bakış açısıyla yorumlayan, edebiyat ile çevre, ekoloji ile kültür arasındaki ilişkileri inceleyen tek akımdır" (Oppermann, 2012: 9).

En genel ifadeyle edebiyat metnini çevreci bir yaklaşımla irdeleyen ekoeleştirinin hareket noktası, insanın doğaya mutlak hâkim olduğu yönündeki yanlış anlayıştır. Küresel boyuttaki çevresel krizin temelinde insan merkezli iktisadî, siyasî ve düşünsel yaklaşımlar yatmaktadır. Ekosistemin bir parçası olduğunu unutarak tüm doğal kaynakları kontrolsüzce kullanıp canlılara zarar veren insanlık, tüketici 
kültürün etkisiyle dünyaya ve doğaya karşı acımasız bir tutum geliştirmiştir. Ekolojik düzene saldırarak çevresel felaketlere kulak tıkayan bu sömürü zihniyeti, aynı zamanda bunu kendinde bir hak olarak görmüştür (bkz. Bulut, 2020: 627). Ekoeleştiri, 'insanın doğadaki tek ve en değerli varlık olduğu' yolundaki alışıldık görüşü reddetmiş, sadece insanın değil doğal dengeyi oluşturan her öğenin ve tüm canlıların hakları olduğu görüşünü öne çıkararak yazınsal eserlerde çevresel sorunlara, insan-doğa ilişkilerine odaklanmıştır. Ekoeleştirinin öncülerinden Scott Slovic'in Edebiyat adlı makalesinde belirttiği gibi, ekoeleştirinin getirdiği önemli yeniliklerden biri edebiyat çalışmalarını insan-toplum boyutundan çıkarıp daha geniş bir perspektif olan insan-fiziksel çevre boyutuna taşımasıdır (akt. Gökçek, 2020: 60). Ekoeleştiriden önce metin incelemelerinde eserlerdeki karakterlerin sosyal ilişkileri, politik durumları, içsel ve psikolojik deneyimleri ele alınırken ekoeleştiriyle birlikte insanların çevreyle olan ilişkileri incelenmeye başlanmıştır.

Edebi eserde bir mekân olarak doğa, doğanın ele alınış şekilleri, doğa tasvirleri, doğa yazını türü ve en geniş olarak insanın çevresinde var olan her şey ekoeleştirinin araştırma alanına girer, böylelikle doğa, eserlerde arka plan olarak kalmaktan çıkarak özne durumuna yerleşir. İnsanın fiziksel çevresiyle olan ilişkilerini ve doğaya olan bakışını değiştirme amacı güden ekoeleştiri, insan eliyle oluşan doğa katliamına yeni bir bilinçle yaklaşmayı hedeflemiştir. Ekoeleştiri, bu türden çalışmalarla doğaya karşı bir duyarlılık yaratıp, insanın fiziksel çevresiyle olan ilişkilerini tekrar gözden geçirme olanağı sağlayarak, ekolojik bilinçlendirme oluşturmak ve bu yolla doğanın kötü muameleye maruz kalıp bilinçsizce yok edilmesini önleme işlevlerini üstlenmiştir.

\section{Edebiyatta Romantizm Akımı}

Çalışmanın ilerleyen bölümlerinde etraflı bir inceleme ile ele alınacak olan Romantizm akımının oluşumuna ve genel hatlarına kısaca değinmek gerekirse; "Romantizm" kavramı, köken olarak "romance" kelimesinden türemiştir. "Romance", Roma İmparatorluğu'nda halkın konuştuğu ve Latince'nin bozulmuş hali olan konuşma dilidir. Halk, ilim dili olan esas Latinceyi bilmez. Zamanla romance, halkın ilgi duyduğu olağanüstülüklerle dolu, tabiat güzelliklerinin anlatıldığı şiir ve nesir türü eserlerin bu niteliğini belirten sıfat olmuş ve söz konusu nitelikler için kullanılmaya başlanmıştır (bkz. Çetişli, 2006: 67). 18. Yüzyıl boyunca da bu sıfat hissedilir bir anlam düşmesi ve anlam kayması geçirerek gerçek dışı, hayali, duygusal anlamlarında kullanılmıştır (bkz. Aytaç, 2005: 233).

Diğer birçok kavramda olduğu gibi, romantizmin oluşumu da, Avrupa'da zorlu ve sancılı bir yolculuğun neticesinde feodal düzenden modern kapitalist düzene geçişe paralel olarak, uzun bir zaman dilimine yayılmıştır (bkz. Aksakal, 2010). Bir edebiyat ve sanat akımı olarak romantizm, 18. yüzyıl başından başlayarak yarım asırlık bir dönemde öncelikle Avrupa'da olmak üzere tüm dünyada geniş bir yankı uyandırmıştır. Genel çerçevede bakıldığında tüm batı toplumlarının sanatlarında yüzde yüz aynı değer ve niteliklere sahip tek bir romantizmden bahsetmek zordur. Farklı tesirler, farklı sosyal ve kültürel şartlar ister istemez farklı romantizmleri meydana getirmiştir. Romantik düşünce ülkeden ülkeye bazı farklılıklar göstermiştir. İngiltere'de romantizm tamamen estetik bir hareketti. Fransa'da ise Rousseau'dan ilham alan romantizm daha çok toplumsal eleştiriydi. Almanya'da 
ise romantizm estetik bir hareket olarak ortaya çıkmış; ama kısa zamanda genişleyerek bir dünya görüşü biçimini almıştır (Dellaloğlu, 2010: 16).

Edebiyatta romantizm akımı, klasisizm akımının hâkim olduğu ve aydınlanmanın da etkilerinin hissedildiği bir dönemin insanlarının içinde bulundukları zamanı kavrama ihtiyaçlarının bir sonucu olarak 18. yüzyılın ikinci yarısında ortaya çıkmıştır. Aklın ön planda tutulduğu klasisizme ve Aydınlanmaya tepki olarak, yitirilen romantik duyumsama, edebiyatın ve yaşamın merkezine oturtulmuştur. Aydınlanmanın eleştirel, çözümsel ve bilimsel temel üzerinde yoğunlaşmasının aksine; yaratıcı imgelemin gücünü, duygu ve sezginin rolünü yücelten romantizm kavramı, dönemin birçok düşünürü tarafından farklı tanımlanmıştır. Victor Hugo'ya göre romantizm "edebiyat olan Fransız ihtilalidir" (akt. Yetkin, 1967: 30). Fransız İhtilali insan haklarını yok eden bütün baskılara karşı nasıl bir ayaklanma idiyse, romantizm de klasik edebiyatın, sanatçıyı kıskıvrak bağlayan, özgürlüğünü ve kişiliğini elinden alan baskıcı kurallarına karşı öyle bir ayaklanmadır. Romantizm akla dayanan bu kuralları yıktıktan sonra, kişisel duyguların eserlerdeki yolunu açan akımdır.

Arthur O. Lovejoy'un birden fazla ve birbirine zit özelliklerdeki romantizmler yüzünden terimin anlamını kaybettiği iddiasına karşılık Rene Wellek ortak bir romantizm anlayışından söz edilebileceğini öne sürmüştür. Rene Wellek, romantizmi 18. yüzyıl boyunca yavaş yavaş yükselen bir Avrupa akımı olarak isimlendirmiş ve romantizmler arasında bir benzerlik olmadığ yanıtı vermiştir: "Aksine, tabiat ile, hayal ile ve sembol ile alakalı romantik görüşler arasında derin bir uyum ve karşıllklı sorumluluk vardır” (akt. Depe, 2019: 58). Son tahlilde denilebilir ki romantizm akımı, uluslara ya da alanlara göre kalıplara sokulamayan, kendi kültürel zenginliğini kabul ettiren ve çeşitliliğini devam ettiren bir dünya görüşü halini almıştır. Bu nedenle eserde bulunan romantik unsurlar hem erken dönem romantizm ilkeleri hem de romantizmin son yüzyılda evrildiği haliyle post/romantik unsurlar çerçevesinde incelenecektir.

\section{Sür Pulluğunu Ölülerin Kemikleri Üzerinde Adlı Eserde Post/Romantik Unsurlar}

Olga Tokarczuk, Sür Pulluğunu Ölülerin Kemikleri Üzerinde'de doğa ile insan karşıtlığının gelmiş olduğu noktayı eleştirel bir tutumla kaleme almıştır. Tokarczuk kendi romanını 'politik bir broşürün unsurları olan bir peri masalı' olarak ifade etmiştir (bkz. Karnewar, 2020).Eser şehirden uzak küçük bir köyde münzevi bir yaşam süren Janina Duszejko karakterinin manevi anlamda adalet arayışıdır denilebilir. Altmışlı yaşlarında olan Janina Polonya'nın Çekya sınırına yakın bir köyde, haftada bir gün köy okulundaki çocuklara İngilizce dersi vererek, geri kalan zamanında kışın kente göçen sahiplerinin yokluğunda çürümesinler diye civardaki evlerin bakımıyla ilgilenerek ve arkadaşı Dzyio ile birlikte William Blake çevirileri yaparak yaşamını sürdürmektedir. Sadece kendisi gibi yaşamın köşesinde kalmış kendi taktığı isimlerle Dyzio, Garip, Müjde ve Boros'la iyi arkadaşlık kurar. Onu sadece onlar anlamaktadır. Janina, insanın hem başka insanlar hem de doğa ve hayvanlar üzerindeki hiyerarşik konumuna isyan etmektedir. Doğaya ve hayvanlara karşı duyduğu tutkuya varan ilgisi sebebiyle köy halkı tarafından 'tuhaf ve kaçık' olarak anılan Janina karakterinin alt metninde, devlet otoritesine, kapitalist sisteme, dini dogmalara, insanın merkeze konduğu ve doğanın, hayvan ve bitkilerin 
acımasızca katledildiği yaşama biçimine bir başkaldırı yatmaktadır. Olaylar köyden birinin ölümü ile başlamaktadır. Bunu takip eden bir dizi esrarengiz ölüm polis tarafindan araştırılırken; bu cinayetlerle ilgili olarak Janina'nın ilginç bir teorisi vardır: Ona göre hayvanlar kendilerini katleden insanlardan intikam almaktadırlar. Kasabada işlenen seri cinayetlerin az çok birbiriyle bağlantısı kurulabilmekte ancak elinde pazar poşetiyle dolaşan yaşlı bir kadından kimse şüphelenmemektedir. Romanın sonuna kadar cinayetler bir türlü çözülemez. Bütün giz bu poşettedir. Janina, cinayetleri bu poşete koyduğu buz kalıplarıyla işler ve olay yerlerine geyiklerin avcılardan intikam aldığı teorisini destekleyen izler bırakır. Cinayetleri onun işlediğini polisten önce arkadaşları fark eder ve ona hak vererek Çekya'ya kaçmasına yardımcı olurlar. Janina, bulunduğu durumu ters yüz ederek kendisini acı çeken hayvanların intikam almasının bir gönüllü aleti olarak görür ve işlediği cinayetlerden hiç pişmanlık duymadan arkadaşlarıyla bağlantılı olarak Çekya'da yeni bir hayata başlar. Çünkü o kendince kendini savunamayanların savunucusu olmuştur ve bunu son derece meşru görmektedir. Defalarca şikâyet ettiği ve yasaklanmasını istediği avcılık vahşetiyle ilgili beklediği adalet kapısından umudu kesip kendi adaletini gerçekleştirmiştir.

Romantizm akımıyla birlikte "insan ruhunun soyut olarak ele alınması bırakılmış ve kişiler çevreleri içerisinde ele alınmıştır. Romantiklere göre kişiyi suça iten, toplumdur. Bu nedenle kişinin düzeltilmesi yerine toplumun düzeltilmesi amacinı gütmüşlerdir” (Ergun, 2005: 227). 'Sanat toplum içindir' düsturunu benimseyen romantik yazarlar eserlerini toplumu bilinçlendirmek ve iyiye yöneltmek için kaleme almışlar, bir anlamda topluma liderlik etme görevini üstlenmişlerdir. Romantik "yazarın, edebiyatın toplumsal bir görevi vardır. Yazar kendini topluma, insanlığa adamalıdır. Edebiyat toplumsal problemlere, toplumsal gelişmelere çözüm aramalıdır" (Göker, 1982: 33). Romantik edebiyatta olduğu gibi ekoeleştiride de fayda unsuru yazarların ve eleştirmenlerin odak noktasıdır. Ortaya çıktığı dönemden itibaren romantik yazın ait olduğu toplumun aksayan yönlerini ortaya çıkarıp bunları onarma yolunda bir çabayla eser üretmiş̧ir. Post/romantik özellikler atfedeceğimiz ekoeleştirel yaklaşım da 20. ve 21. yüzyılın en dikkat çeken küresel sorunu olan çevre katliamına eğilmiştir. Çevre sorunlarına karşı edebiyat aracılığıyla insanların hassasiyetlerine yönelerek doğa bilinci oluşturmayı amaçlayan Olga Tokarczuk, bir yazar olarak yüklendiği misyonu eserinde şu sözlerle ifade etmiştir: "Ancak bütün bunlara, kırılganlığımıza ve cahilliğimize rağmen (...) zaman bizim için çalışıyor, acı çeken, ağrıyan dünyayı mutlu ve barışç1l bir yer haline dönüştürmek için bize firsat veriyor. (...) Bu nedenle süreç içinde insan hassasiyetini canlandırmalıyız (Tokarczuk, 2020: 236-237).

\subsection{Post/Romantizmde Doğa Unsuruna Ekoeleştirel Bakış}

Romantizmin temel unsurlarından biri doğadır. Tabiat romantik yazarlar için sonu gelmez bir ilham kaynağı olmuştur. Kemal Suut Yetkin, romantik yazar ve şairlerin doğa tutkusunu şu şekilde ifade etmiştir: "Hiç bir çağ, romantik çağ kadar tabiat1, 'Issız yer'i, 'Göl'ü, 'Göklerin Sonsuzluğu'nu, 'Geceler'i, 'lş1k ve Gölgeler'i, 'Son bahar yaprakları'nı, 'Küçük Vadi'si ile bu kadar içten sevmemiş, dile getirmemiştir" (Yetkin, 1967: 33). Romantikler için doğa, sadece bir arka plan olmaktan çıkmış; edebi eserin ayrılmaz bir parçası haline gelmiştir. Buna paralel olarak romantiklerin doğaya düşkünlügünü bir parça daha ileriye götüren ekoeleştirel yaklaşım, bir edebi metinde eşitlik ilkesine dayanarak doğada bulunan 
bütün canlıları insan merkezli olmaksızın özne yerine koymuştur. Bu bakış açısına göre insanın doğaya karşı üstünlüğü reddedilerek insan-doğa ilişkisinin uyum içinde sürmesi gerekliliğine vurgu yapılmıştır. Görülmektedir ki söz konusu iki yaklaşım için de dağlar, denizler, ormanlar, hayvanlar, bitkiler ve insanlar ayrılmaz bir bütünün ahenkli birer parçasıdır (bkz. Gariboğlu, 1976: 208-209). Bu bütünlük vurgusu ele alınan romanda da dikkat çekmiştir: "Ve dünya, hiçbir şeyin ayrı olarak var olmadığı büyük bir ağ, bir bütündür. Dünyanın her bir kırıntısı, son küçük parçasına kadar, sıradan bir aklın kavraması zor olduğu, karmaşık Kozmos ilişkileri sayesinde geri kalanıyla bağlantılıdır" (Tokarczuk, 2020: 69-70).

Erken dönem romantik yazarların büyük önem atfettiği, eserlerinin temeline koydukları insan-doğa ilişkisi sanayileşme ile birlikte geri dönülmesi güç biçimde bozulmuştur. Modernleşme sürecinde gelişen teknoloji, kurulan fabrikalar, inşa edilen büyük şehirler, kapitalist sisteminin getirisi olan uzun çalışma saatleri insanlığı kapalı mekâna hapsetmiş ve doğayla bağlarını kopma noktasına getirmiştir. Eserde köyün yakınlarında bulunan bir maden ocağı aracılığıyla makineleşmenin sebep olduğu doğa katliamına ve tüketim biçimlerine eleştiri getirilmiştir:

$\mathrm{Bu}$ dik yola Geçit deriz. Ayrıca yakında sarp bir kayalık vardır, ama burası yayladan parçalar çıkarmak için kullanılan ve hepsinin sonunda kazıcıların açgözlü ağızlarında tüketildiği eski bir madenin kalıntılarıdır, doğal bir yaratı olduğunu düşünen yanılır. Tekrar çalıştırmak için planlar olduğu söyleniyor, işte o zaman Dünya yüzünden silinip, Makineler tarafından yutulacağız (Tokarczuk, 2020: 61).

Romantizmdeki bir diğer önemli ilke ise doğa ile bağlantılı olarak tasvirdir. Öznel bir bakış açısını benimseyen romantik yazar ve şairler için tabiatı taklit etmek değil tasvir etmek esastır. Dış dünyanın algılanan gerçekliğinden ziyade önemli olan o manzaranın yazarda uyandırdığı hislerdir. Romantikler çok detaylı betimlemelerle doğanın görünen ve görünmeyen yanlarını okura sezdirmeyi, derin bir anlam dünyası oluşturup okuru bu dünyanın içine çekmeyi hedeflemişlerdir. Mina Urgan, romantizm akımındaki tasvir geleneğini şu şekilde açıklamıştır:

Romantik şairler doğanın dış görünüşünün güzelliğini ya da dehşet uyandıran gücünü anlatmakla yetinmediler. Dünya yeni yaratılmış da, onu ilk görenler kendileriymiş gibi, çevrelerine yepyeni gözlerle bakmasını bildiler; insanoğlunun doğa karşısında duyduklarını saptadılar; hayal güçleri sayesinde doğanın gözle görülmeyen özünü, gizli anlamlarını sezdiler; doğayı bize yeniden yorumladılar ve insanla doğanın kaynaşmasını, doğa sayesinde insan yaşamının zenginleşip renklenmesini sağladılar. İşte bu yüzdendir ki, Romantik çağdan önce yazılan doğa şiirleri derinlik ve gerçeklikten yoksun, lafta kalan betimlemeler izlenimini verir bizlere (Urgan, 2015: 506).

Olga Tokarczuk, Sür Pulluğunu Ölülerin Kemikleri Üzerinde romanında doğayı eserin odak noktasına koymuştur. Tıpkı 18. yüzyıl romantik eserlerindeki uzun betimlemeler gibi bu eserde de doğa tasvirleri önemli bir yere sahiptir. Basit bir manzaranın detaylı ve içtenlikli anlatımı ile yazarın duygusu okura geçmektedir:

Önümde açılan manzara, siyah ve beyazın gölgelerinden, tarlalar arasındaki sınırlar boyunca, çizgiler halinde birbirlerine sarılmış ağaçlardan oluşuyordu. Otların kesilmediği yerlerde kar, tarlaları, yekpare beyaz bir örtü gibi kaplamakta başarılı 
olamamıştı. Otların uçları beyaz örtüyü delip çıkıyorlardı. Uzaktan kocaman bir el, kısa darbelerle, ince ve ustaca soyut bir şekil karalamaya başlamıştı sanki. Şeritler ve dikdörtgenler halinde, hepsi farklı dokuda, her biri kendi gölgesine sahip, kışın hızlı Günbatımına karşı farklı açılarda eğimli olmak üzere tarlaların hoş geometrik şekillerini görebiliyordum. Ve hepsi yedi tane olan evlerimiz, burada sanki tarla sınırlarıyla birlikte ortaya çıkmış da doğanın bir parçası olmuş gibi dağılmışlardı, tıpkı dere ve üzerindeki küçük köprü gibi; çizimleri yapan aynı el tarafından hepsi özenle tasarlanmış ve konumlandırılmış gibi görünüyorlardı (Tokarczuk, 2020: 60).

Romantik metinlerdeki tabiat tasvirleri yazarın ruhsal durumunun da bir yansımasıdır. Değişken ruh durumuna göre bu tasvirler güneşli, parlak, umut verici bir manzarayı anlattığı gibi kimi zaman da karanlık, boğucu, iç karartıcı anlatımları da içerebilir. Tokarczuk, doğadan kopmuş ve onunla bir savaşa girmiş insanlığın tablosunu da soğuk, karlı bir iklimde, günlerin kısa sürdüğü, uzun karanlık gecelerin hâkim olduğu bir coğrafyada hâkim olan karamsar bir atmosferde anlatmaktadır. Bu yolla yazar hem kendi yüklendiği sorumluluğun ağırlığına hem de insanlığın düşmüş olduğu yanlışa gönderme yapmaktadır. Ancak ne olursa olsun bu noktadan kurtuluş için çareyi yine doğada aramaktadır. Romantik yazar için doğa bir kaçış yeridir (bkz. Çetişli, 2006: 74).

Yalnız bir dişi kurt gibi alanımı genişletiyordum. Evlerin ve yolun manzaralarını arkada bıraktığım için ferahlamıştım. Ormana gidecektim-sonsuza kadar kaybolarak dolaşabilirdim. Burada her şey daha sessizdi, orman birinin saklanabileceği büyük, derin bir sığınak gibiydi. Zihnimi sakinleştirmişti. Burada rahatsızlıklarımın en belalısını saklamak zorunda değildim, yani ağladığım gerçeğini. Burada gözyaşlarım akabilirdi, gözlerimi yıkayıp görmemi iyileştirirdi (Tokarczuk, 2020: 171).

\section{2.İnsan-merkezcilik Yerine Canlı-merkezcilik}

Romantizm akımı ferdiyetçidir. Klasisizmin katı kuralcılığ etme imkânı bulamayan yazar ve şairler, Romantizm dönemi ile bireye ve ona ait olan her şeye büyük bir tutkuyla kapılmışlardır. Tarihsel süreç içinde bu bireycilik ve insan-merkezci yaklaşım insanın kendini diğer tüm canlılardan üstün görmesi ile ilişkilendirilmiştir. İnsanın kendini doğanın üstünde konumlandırışı, doğal çevrenin yıkımı, hayvan haklarının ihlali, insanın doğaya egemen olma ve doğal değerler üzerinden para kazanma ihtirası, doğayı bilinçsiz ve sevgisizce yok etmeye yönelik eylemleri, kendi dışındaki canlılara karşı acımasızlığı ile sonuçlanmıştır. Ekoeleştiri bu insan-merkezci bakış açısını reddetmiş ve eşitlik zemininde kurulacak bir doğa-insan ilişkisinin temellerini atmayı hedeflemiştir. Eserinde insan-merkezci bakış açısının verdiği zararları göstermeye çalışırken insanın çevreye karşı temel sorumlulukları üzerine düşündüren Olga Tokarczuk da, canlımerkezci bir anlayışı savunmaktadır. Bunun izlerini eserde en belirgin olarak Janina'nın 'Koca Ayak' adını taktığı komşusunun davranışlarında ve yaşama biçiminde görmek mümkündür.

Ormanı da iyi biliyordu-hangi kısımlardan para kazanılır, ne kime satılır. Mantarlar, bögürtlenler, çalınmış kereste, yakmak için çalı çırpı, tuzaklar, yıllık otomobil rallisi, avcılık. Orman bu küçük cini beslemişti. Bu nedenle onun ormana sayg1 göstermesi gerekirdi, ama göstermemişti. Bir Ağustos, kuraklık zamanı, bir bögürtlen alanını ateşe vermişti. Yazın testereyle gezer yaş ağaçları keserdi. (...) 
Sanki onları yolundan itmek istermişçesine homurdanıp ağaç gövdelerine sopayla vururdu, bir sarhoşluk ortamına doğmuş gibi görünürdü. Çoğu zaman izlerini takip edip Hayvanlar için kurduğu ilkel tuzakları, tuzağa düşen hayvanların havada asılı kalmalarına neden olacak şekilde eğilmiş genç ağaçlara bağlanmış ilmikleri toplardım. Bazen ölü Hayvanlar bulurdum-Tavşanlar, Porsuklar ve Geyikler (Tokarczuk, 2020: 16-17).

Amerikalı filozof ve çevrebilimci Aldo Leopold Bir Kum Yöresi Almană̆ adl $_{1}$ eserinde insanlar arasında var olan etik kavramının doğayı da içine alacak şekilde genişlemesi gerektiğine dair fikrini öne sürmüştür. Kitabının Toprak Etiği başlıklı makalesinde yer verdiği bu görüş çevrebiliminde ve ekoeleştiride yeni bir çığır açmıştır. Leopold'un toprak etiği kavramına göre toprağın ve üzerinde yaşayan tüm canlıların insana olan faydasından bağımsız içsel bir değeri vardır. Bu bağlamda doğa ve üzerinde yaşayan canlılar ekonomik değere sahip oldukları için değil içsel değerlere sahip oldukları için kıymetlidir (bkz. Özdağ, 2014: 22). Bu etik anlayış, insan-merkezciliğine son verip canl1-merkezciliği gündeme getirmiştir.

Sür Pulluğunu Ölülerin Kemikleri Üzerinde romanında Janina karakteri insanın kendini doğanın efendisi gibi konumlandırmasına karşı bir savaş vermektedir. İnsan tahakkümündeki doğanın tahrip edilişine, hayvanların insanların malı olarak algılanışına, bitki örtüsüne zarar veren madenlere, hayvanları vahşice öldürmenin meşrulaştırıldı̆̆ı bir spor, bir hobi olarak görülen avcılığa karşı bireysel bir mücadeledir bu. "Hayvanlar, yaşadıkları ülke hakkındaki gerçekleri gösterir, Hayvanlara olan yaklaşım yani. İnsanlar hayvanlara vahşice davrandıklarında, hiçbir demokrasi biçimi onlara yardımcı olmaz, aslında hiçbir şey yardımcı olmaz" (Tokarczuk, 2020: 118). Janina'nın isyanı hem toplumsal hem de evrenseldir.

Canlı-merkezci yaklaşımda dünyadaki her varlığın bir ruhu olduğuna ve bu varlıkların da çevreleri ile iletişim içinde olduğuna inanılmaktadır. Leopold'un toprağın, bitkilerin ve hayvanların içsel 'enerji'si olarak nitelendirdiği bu ruh animizm kavramıyla açıklanmaktadır. Animizm (canlıcılık) adı verilen bu inanca göre "dünyada yaşayan her canlının bir ruhu vardır, insanın kendi çevresindeki ilişkileri, insanın diğer bir insanla olan ilişkileri gibidir, taş ya da nehir, ağaç hep canlı bir ruha sahiptir ve bu varlık ile ruh arasındaki ilişki süreklidir" (akt. Bulut, 2020: 628). Bu da ruh sahibi olduğuna inanılan doğaya ve doğadaki her varlığa saygı göstermeyi ve onlarla uyum içinde yaşamayı zorunlu kılmaktadır.

Çalışmada ele alınan romanda Janina hayvanları koruma, onlara sahip çıkma görevini üstlenmiştir. O'na göre doğada var olan hiçbir yaratık yararlı ya da yararsız diye ayrılmaz; sadece var olurlar. İnsanların göreviyse onların varlığına müdahale etmemek ve varlıklarına saygı duymaktır. Eserde Janina hayvanlara şöyle seslenmektedir:

Av kulübelerinden uzak durun, buradan size hayır gelmez, oradan iyi haber duymazsınız, ölümden sonra kurtuluşu vaat etmezler, ruhlarınız olmadığını iddia edip zavallı ruhlarınıza merhamet etmezler. Sizi yakınları olarak görmezler, size destek vermezler. En kötü suçlunun bile ruhu vardır, ama senin yoktur güzel Geyik, ne de senin Yaban Domuzu, ne de senin Vahşi Kaz, ne de senin Domuz, ne de senin Köpek (Tokarczuk, 2020: 122). 
Modern insan, hayvanları kendi kurduğu şehir yaşamında ya hayvanat bahçelerine hapsetmiş ya da onların etini, sütünü, yumurtasını, balını hızla tüketip onları "av sporuyla" katlederek uygarlık yanılsamasına kapılmıştır. Bu da yetmezmiş gibi kendinden güçsüz olan bu hayvanları, fabrika benzeri mekânlara kapatıp 1sı ve 1şık altında sürekli yavrulatarak onları özlerinden koparmıştır. Bu yağmacı ve gaddar tutum Janina'nın romantizm ruhu taşıyan hassas ve duyarlı karakterinde can bulmuştur:

Nasıl bir dünya bu? Birinin gövdesi ayakkabı, köfte, sosis veya yatağın önüne serilen halı oluyor, birinin kemikleri çorba yapmak için kaynatılıyor... Birinin karnından ayakkabılar, kanepeler, çantalar yapılıyor, birinin kürküyle ısınılıyor, birinin eti yeniyor, küçük parçalara bölünüp yağda kızartılıyor. Dâhice felsefelere ve teolojilere birçok düşünce uygulanmış olmasına rağmen, bu felaket, bu kitle katliamı, zalimce, ruhsuz, otomatik olarak, vicdanlar sızlamadan, bir an bile düşünmeden sahiden gerçekleşiyor mu? Öldürmenin ve acının ilke olduğu nasıl bir dünya bu? Bizim neyimiz var? (Tokarczuk, 2020: 124).

Çevreci yaklaşımların önerdiği yaşam biçiminde insan, merkezdeki konumunu terk eder ve çevresi ile eşit düzeyde yer alır. Çevreyi korumak için sadece bilinçli olmanın yeterli olmadığını söyleyen Leopold, insanın sorumluluk yüklenmesi gerektiğini savunmuştur. Ait olduğu çevreye karşı yükleneceği sorumluluk duygusu insanı doğru ve yanlışı ayırt etmeye itecektir. Leopold'un doğru ve yanlış kavramı oldukça basittir: bir şey biyotik toplumun bütünlügünü, dengesini ve güzelliğini koruyorsa doğru, değilse yanlıştır (akt. Genç, 2007: 38).

\subsection{Post/Romantizmde Din}

Romantik sanatçıların dini inanışları, tabiatla olan bağları ile ilintilidir. Romantikler Panteizmi yani Tanrı ile kâinatın tek varlık olduğunu kabul eden inanışı benimsemişlerdir. Gürsel Aytaç, Romantizmdeki din olgusunu şu şekilde ifade etmiştir:

Evrenin ve hayatın temeli, kayıtsız şartsız var olan ilk öz, her çeşit canlılığı bir bölünme, kendinden ayrılıp bireyleşme şeklinde yaratmıştır ve en sonunda bunları yine özünde toplayacaktır. Romantikler, panteizmi Hıristiyanlıkla bağdaştıran bir Tanrı görüşünü benimsemişlerdir. $\mathrm{Bu}$ devrin din görüşü, insanın tabiata olan bağını, onun tabiatı değerlendirişini ve sanat yaşantısını belirlemiştir (Aytaç, 2005: 176).

Her ne kadar Romantik sanatçılar doğayı, edebiyat eserlerinin ve yaşam biçimlerinin merkezine koymuş olsalar de tarihsel arka planda doğa her zaman insandan sonra gelmiş ve insana tabi kılınmış bir unsurdur. İnsanın doğayla olan ilişsisinde doğada bulunan tüm canlı ve cansızları gelecek yokmuşçasına tüketip tahrip etmesi yalnızca bedensel istek ve gereksinimlerinden kaynaklanmamaktadır. Aksine, bir takım dini buyruk, kurum ve metinlerde de insanın doğanın sahibi olduğu sanıs1 meşrulaş̧ırılmıştır (bkz. Arıkan, 2011: 44). Derin ekolojinin kurucularından Arne Naess insanı doğadan üstün gören anlayışın köklerini tek Tanrılı dinler ve Batı felsefesinde aramıştır (akt. Bulut, 2020: 628). Aklın üstünlüğünü savunan Batı felsefesi ve tek Tanrılı dinlerin bazı öğretileri doğayı insanın hizmetine sunulmuş bir varlık gibi göstererek insana doğaya hükmedebileceği düşüncesini aşılamıştır. Sür Pulluğunu Ölülerin Kemikleri 
Üzerinde romanında bu yaklaşımın temsili bir rahip aracılığıyla yapılmıştır: "Rahip öfkeyle kıpırdanmıştı. "Hayvanlara insanmış gibi davranmak yanlıştır. Tanrı hayvanlara, insanların hizmetinde, daha alt bir sınıf vermiştir. (...) Hayvanların ruhları yoktur, ruhları ölümsüz değildir. Selameti bilmezler" (Tokarczuk, 2020: 262).

18. yüzy1l Romantikleri, kendilerinden önceki katı Hıristiyanlığın yerine doğainsan uyumunu ön plana çıkartan daha 1 lımlı bir inancı benimsemişlerdir. Romantizm ve ekoeleştirinin ortak noktalarından olan insanı doğadan üstün görmeyen yaklaşımlarıyla kendi çağlarındaki çevresel sorunlara değinmişler, bunu eserlerine yansıtmışlardır. Ancak modernleşmeyle insanın çevresiyle olan bağları kopmaya başlamış ve yeniden üstün konuma geçmiştir. Günümüzde çevreci hareketlerle bu konum yeniden sarsılmış ve doğa-insan eşitliğine dikkat çekilmiştir.

Tokarczuk romanda, başta Hıristiyanlık olmak üzere insan merkezli dini inançlara eleştiri yöneltmiştir. Janina'nın 'Peder Hışırtı' adını taktığı rahip, eserde dini otoriteyi temsil etmektedir. Köydeki avc1ların koruyucusu olan ve kendisi de avlanan rahip aracılığıyla Hıristiyanlıkta hayvanlara yaklaşım eleştirel bir dille kaleme alınmıştır.

Bildiğiniz gibi, sevgili kardeşlerim, bir süredir cesur avcılarımızın koruyucusu oldum. Onların kutsal öncüsü olarak avcılık karargâhını kutsuyorum, toplantılar düzenliyorum, dini törenler yönetiyorum ve ölenleri 'edebi avlanma alanlarına' gönderiyorum, ayrıca avcılık etiğiyle ilgili meselelerle ilgileniyorum ve avcılara ruhsal destek sağlamak için elimden geleni yapmaya çalışıyorum (Tokarczuk, 2020: 266).

Janina insanların, hayvanlara tuzak kurarak avlanmasını, birini yemeğe davet edip öldürmeye benzetmektedir (267). Ve eğer gerçekten iyi bir Tanrı varsa, bu korkunç riyakârlığa tamamen son vermesini istemektedir (265). Ancak böyle bir müdahalenin şimdiye kadar olmadığını, gelecekte de olmayacağına dair bir inancı vardır (266). Böylece yazar, sadece Hıristiyanlığa değil, Tanrı inancına da eleştiri yöneltmiştir.

Görülmektedir ki insanlık doğa ile yüzyıllardır süren bir savaş halindedir. Zaman zaman bu kısır döngü duyarlı yaklaşımlarla kırılmaya çalışılmış ama sistem kendini hızla yenilemiş ve savaşa kaldığı yerden devam etmiştir. 21. yüzyıla gelindiğinde hala 18. yüzyıl romantikleri ile aynı noktada olunması; insanlığı küresel çevre krizlerin eşiğinde bir çıkmaza hapsetmiştir.

\subsection{Post/Romantizmde Duygular, Hayaller ve Hürriyet}

Romantizm akımı Klasisizme tepki olarak doğmuştur. Bundan dolayı romantizmin pek çok ilkesi Klasisizmden yola çıkılarak, ona karşıt olarak ortaya çıkmıştır. Klasisizm dönemi katı kuralcı, aklın ve mantığın rehber olduğu, sanatçıyı kısıtlayıcı bir akımdır. Romantikler bu dönemin tüm kurallarını reddederek kendi sanatlarını oluşturmuş ve kendilerine bir özgürlük alanı yaratmışlardır. Bundan dolayı Romantik edebiyatta 'hürriyet' temel ilkelerden biridir. Sanatçının hayal dünyasına, yaratıcı gücüne ve duygularına ket vuracak her kural yıkılmış ve yerine özgürlükçü bir yaklaşım getirilmiştir. Olga Tokarczuk'un eserinde Janina'nın hayal gücünde canlandırdığı dünya, romantizmin neredeyse tüm temel ilkelerini barındıran post/romantik bir dünyadır: 
Burada İnsanlık aptal ve sıkı mantık kuralları yerine yürek ve sezgiyle yönetilir. İnsanlar bildikleri şeyleri ilan ederek, gereksiz gevezelikten keyif almazlar, onun yerine hayal güçlerinin peşinde dikkate değer şeyler yaratırlar. Devlet günlük baskı uygulamalarını sona erdirip insanlara umut ve hayallerini gerçekleştirmede yardımcı olur. Ve İnsan, sadece sistemdeki bir dişli, sadece bir rol sahibi değil, özgür bir Yaratıktır (Tokarczuk, 2020: 98).

Romantizmle birlikte insanın iç dünyasına, duygularına yöneliş olmuştur. Ancak söz konusu edilen duygular çoğunlukla melankoli ve hüzündür. Başta Avrupa olmak üzere tüm dünyayı derinden etkileyen Fransız Devriminden sonra insanlık umutsuzluğa sürüklenmiştir. Devrimden beklenen eşitlik, kardeşlik, adalet, hürriyet gibi temel değerlerin yerini burjuvaziyle yükselen yozlaşma almıştır. Bu da insanlığı büyük bir hayal kırıklığına sürüklemiş ve Romantizm dönemi edebiyatına karamsar bir atmosfer olarak yansımıştır. Bu atmosfer günümüzde halen varlığını sürdürmekte ve 18 . yüzy1ldan günümüze kadarki süreçte romantik hassasiyeti ve melankoliyi sürdürecek nükleer savaşlar, küresel boyutta yaşanan ekonomik krizler, iklim değişiklikleri ve çevre kirliliği gibi yeni pek çok mesele ortaya çıkmıştır. Böylesi sorunlar, insanların yaşamları üzerinde çok önemli etkiler meydana getirebilmektedir. Hatta insanların yaşamlarını farklı yerlerde devam ettirme kararı alarak göç etmelerine bile neden olabilmektedir (bkz. Cihangir, 2020: 21-22). Dolayisiyla bu meselelerin edebiyata yansimaması da mümkün değildir.

Tokarzcuk, çevre duyarlılığıyla kaleme aldığ romanında post/romantik bir karakter olan Janina ve onun bireysel mücadelesiyle okura karamsar bir atmosfer sunmuştur. Bu karamsarlığın insanlığı farkındalığa sevk etmek, bilinçlendirmek amacıyla bilinçli yapılmış bir seçim olduğu düşünülebilir.

Evet, Dünya'yı tutulmuş gibi görüyorum. Zalim bir çocuk tarafindan kutuya hapsedilmiş Mayıs böcekleri gibi, sonsuz bir Kasvet içinde körlemesine hareket ettiğimizi görüyorum. Kendimize zarar vermek ve özümüzü yaralamak kolay, karmaşık olarak yapılmış, tuhaf varlığımızı parçalamak. Her şeyi anormal, korkunç ve tehditkâr olarak yorumluyorum, sadece felaket görüyorum. Ama Düşüş başlarken daha da aşağıya düşebilir miyiz? (Tokarczuk, 2020: 72).

Romantizm döneminde ortaya çıkan özgürlük, hayalperestlik ve duygu odaklı sanat anlayışı yazarları insanın ve evrenin farklı özellikleri keşfetmeye ve bunu eserlerine yansitmaya yönlendirmiştir. Klasisizmde ideal-üstün-iyi-güzel-zengin kalıbı içinde çizilmeye çalışılan insana karşılık olarak; Romantizmde çirkinlik, kötülük, fakirlik gibi hayatın içinden kavramlar ele alınmıştır. Bu unsurlar iyi-kötü, güzel-çirkin, zengin-fakir gibi karşıtlık zemininde işlenmiştir. Romantik eserlerde mutlaka iki zıt kutup karşı karşıya getirilmiştir. Sür Pulluğunu Ölülerin Kemikleri Üzerinde romanı da karşıtlıkların hüküm sürdüğü bir eserdir. En başta ele alınan karşıtlık insan-doğa ilişkisidir. İnsan-doğa karşıtlığının alt başlı̆̆ında ise iyi-kötü, adil-adaletsiz, hakl1-haksız, zengin-fakir, suçlu-masum karşıtlıkları işlenmiştir. Tüm bu karşıtlıkların temelinde olumsuz özellikler insanlığa, olumlu özellikler ise doğaya atfedilmiş̧ir.

Romantik eserlerde göze çarpan bir diğer ilke eser sonunda kötülerin cezalandırılması ve iyilerin ödüllendirilmesidir. Çalışmaya konu olan eserin sonunda avc1lık yaparak doğayı, hayvanları katleden herkes ölmüş ve hak ettikleri 
cezayı almışlardır. Adaleti sağlayan ise doğa savaşçısı Janina'dır. Tüm kötülüklerin kaynağı olarak gördüğü avcıları öldürmüş, hayvanları katillerin ellerinden kurtarmış ve hem ölmüş hayvanların ruhlarını hem de acı çeken kendi ruhunu huzura kavuşturmuştur. Kötülüklerin karşısında durarak doğayı savunarak 'iyi' konumunda yer alan Janina'nın ödülü ise adaleti sağlamış olmanın verdiği mutluluğun yanı sıra işlediği cinayetler açığa çıktıktan sonra devlet otoritesinden kaçarak Çekya'da yeni bir yaşama başlayabilmesidir. İlahi adaletten umudunu kesen yazar, kurgusal dünyasındaki adaleti kendi sağlamıştır.

\section{Sonuç}

Bu çalışmada Olga Tokarczuk'un kaleme aldığı Sür Pulluğunu Ölülerin Kemikleri Üzerinde isimli romanda saptanan post/romantik unsurlar ekoeleştirel yöntem ile incelenmiştir. 18. yüzyıl romantizminden izler barındıran ama aynı zamanda bu unsurların günümüze uyarlanmış halini de içeren bu roman, modern dünya eleştirisidir. Çevresel sorunların altında insan merkezci bakışın yattığı mesajını veren yazar, bu bakış açısının yol açtı̆̆ı zararları göstermeye çalışırken okuru insanın çevreye karşı temel sorumlulukları üzerine düşündürmüştür. Janina karakterine yüklediği görev ile insan-merkezci yaklaşıma karşı farkındalık oluşturmaya çalışmıştır.

18. yüzyılda Klasisizme tepki olarak doğan Romantizm akımı sonlanmamış ve romantik ruh kaybolmamıştır; şekil değiştirerek, yenilenerek, uyumlanarak günümüzde varlığını sürdürmektedir. Rönesans, Reform, Aydınlanma, Fransız Devrimi gibi birbirini takip eden ve dünya çapında etki gösteren hareketler sonucu insanoğlu derin bir boşluk hissine kapılmıştır. Bu dönemde yaratılan edebi metinler duygu yoğunluklu ve sosyal mesaj veren eserler olmuştur. Aradan geçen yüzyıllar modern toplumları inşa ederken insanın doğa ile ilişkisinde onulmaz yaralar açmıştır. İnsanlık hem doğaya karşı hem de birbirine karşı büyük bir savaş içine girmiştir; atom bombaları, nükleer felaketler, terör suçları, kapitalist üretimtüketim zinciri gibi örneği çoğaltılabilecek birçok neden insani değerleri zayıflatmış, bireyin insanla ve doğayla ilişkisini tamir edilmesi güç bir noktaya getirmiştir.

İçinde bulunduğu yüzyıldan, toplumdan, coğrafyadan ve kültürden bağımsız düşünülemeyen edebiyat, insanlığın elindeki en etkili araçlardan biridir. Yüzyıllardır yazarlar seslerini dünyaya duyurabilmek, toplumları bilinçlendirmek ve daha ileriye taşımak için eserler üretmişlerdir. Polonyalı yazar Olga Tokarczuk, evrensel çevre sorununu, hayvan katliamları ve doğa tahribatı kapsamında çarpıcı bir kurguyla işlemiş ve okuru sarsan, bakış açısını genişleten bir esere imza atmıştır.

\section{Kaynakça}

Aksakal, H. (2010). "Aydınlanma" Çă̆ından "Karanlık" Yüzyıla Politik Romantizm ve Modernite Eleştirileri. İstanbul Üniversitesi, Sosyal Bilimler Enstitüsü, Basılmamış Yüksek Lisans Tezi.

Arıkan, A. (2011). "Edebi Metin Çözümlemesi ve Ekoeleştiri”. Akdeniz Üniversitesi Edebiyat Fakültesi Dergisi, Cilt 1, Say1 1, 43-51.

Aytaç, G. (2005). Yeni Alman Edebiyatı Tarihi. Ankara: Akçă̆ Yayınları. 
Bayraktar, B. (2015). "Birey-Doğa İlişkisi Temelinde Kendisi Ol(ama)ma: Mustafa Kutlu Öykülerini Ekoeleştirel Okumak”. Turkish Studies Dergisi, Cilt 10, Say1 12, 137-154.

Bulut, F. (2020). "Ekoeleştiri Kuramı Işığında Ayla Kutlu'nun "Huvava: İlk Çevre Koruyucu" Adlı Eserine Bakış". Turkish Studies Dergisi, Cilt 15, Sayı 2, 625-638.

Cihangir, M. (2020). Ötekileşen ve Ötekileştirilen Göçmenler, Türk - Sudan Pakistan Romanları Bağlamında Karşılaştırmalı Bir Inceleme, Efe Akademi Yayınevi, İstanbul.

Çetişli, İ. (2006). Batı Edebiyatında Edebi Akımlar. Ankara: Akçağ Yayınları.

Dellaloğlu, B. F. (2010). Romantik Muamma. İstanbul: Ayrıntı Yayınları.

Depe, D. (2019). Türk Romanında Romantik Bir Tema Olarak Arzu. Eskişehir: Eskişehir Osmangazi Üniversitesi, Sosyal Bilimler Enstitüsü, Basılmamış Doktora Tezi.

Ergun, M. (2005). Şairler Yazarlar ve Edebi Akımlar. İstanbul: Yuva Yayınları.

Gariboğlu, K. (1976). Edebiyat Bilgileri Batıda ve Bizde Edebi Akımlar. İstanbul: Serhat Dağıtım.

Genç, S. V. (2007). "Derin Ekoloji Penceresinden Hayvana Bakış". Veteriner Hekimler Derneği Dergisi, Cilt 78, Say1 2, 35-39.

Gökalp Alpaslan, G. (2013). "Cengiz Aytmatov'un Dişi Kurdun Rüyaları Romanında Doğal Denge ve Hayvan Zihni”. Hacettepe Üniversitesi Edebiyat Fakültesi Dergisi, Cilt 30, Sayı 2, 1-18.

Gökçek, A. (2020). Romantik Şiirden Günümüze İngiliz Şiirinde Doğa Kirliliği Kavramına Ekoeleştirel Bir Yaklaşım, Ankara: Ankara Üniversitesi, Sosyal Bilimler Enstitüsü, Basılmamış Doktora Tezi.

Karnewar, K. V. (2020). The Novels of Olga Tokarczuk: A Study in Myths, History and Culture. Nanded: Swami Ramanand Teerth Marathwada University, The Faculty of Humanities, Basılmamış Doktora Lisans Tezi.

Keskin, G. (2017). “Günümüzde Romantik Olmak Mümkün Mü?”. Asos Journal Akademik Sosyal Araştırmalar Dergisi, Say1 45, 82-92.

Klein, N. A. (2016). “Olga Tokarczuk’un Nesir Yazarlığı Szafa (Dolap) Başlıklı Öyküsü Bağlamında”. İdil Dergisi, Cilt 5, Sayı 27, 1895-1912.

Oppermann, S. (2012). Ekoeleştiri Çevre ve Edebiyat. Ankara: Phoenix Yayınevi.

Özdağ, U. (2014). Çevreci Eleştiriye Giriş. Ankara: Ürün Yayınları.

Sayre, R. \& Löwy, M. (2016) İsyan ve Melankoli: Moderniteye Karşı Romantizm. Çeviren I. Ergüden, İstanbul: Alfa Yayıncılık.

Tokarczuk, O. (2020). Sür Pulluğunu Ölülerin Kemikleri Üzerinde. Çeviren N. Taluy. İstanbul: Timaş Yayınları.

Urgan, M. (2015). İngiliz Edebiyatı Tarihi. İstanbul: Yap1 Kredi Yayınları. 
Yetkin, S. K. (1967). Edebiyatta Aklmlar. İstanbul: Remzi Kitabevi. 